\title{
Analisis tingkat kepuasan nasabah atas pelayanan dengan demografi sebagai variable Moderasi pada Bank Syariah Cabang Binjai
}

Author: Abstrak: Segmentasi demografi seperti usia, jenis kelamin, pekerjaan Suria Alamsyah Putra dan pendidikan akan menjadi salah satu karakteristik responden yang akan memoderasi hubungan antara kualitas layanan dengan kepuasan

Afiliation: STIE Stindo Medan

Corresponding email suryaalamsyah85@gmail.com

Histori Naskah: Submit: 28-05-2021 Accepted: 28-05-2021 Published: 28-05-2021 nasabah. Usia nasabah pada Bank Syariah Mandiri Cabang Binjai menjadi faktor yang perlu dipertimbangkan untuk melihat kepuasan nasabah. Umumnya nasabah yang mengajukan pinjaman paling muda berumur 25-29 tahun hal itu disebabkan karena biasanya pada umur tersebut, nasabah telah mempertimbangkan semua hal yang berkaitan dengan economic factors. Kekecawaan calon nasabah atas lamanya proses tersebut, dikarenakan sistem pelayanan yang kurang baik pada Bank Syariah mandiri. Jumlah karyawan yang bertugas melakukan verifikasi tidak diimbangi dengan banyaknya jumlah calon nasabah yang mengajukan pembiayaan. Untuk itu maka, penelitian ini akan melihat seberapa besar pengaruh pelayanan Bank Syariah Mandiri Cabang Binjai yang terdiri atas tangibles, reliability, responsiveness, assurance, dan emphaty terhadap kepuasan nasabah dengan umur sebagai variabel moderasi. Sampel yang digunakan dalam penelitian ini adalah sebanyak 53 orang dari awal tahun 2013 - awal tahun 2014. Teknik analisis yang digunakan adalah Moderating Regression Analysis (MRA) dengan bantuan Software SPSS. Hasil dari penelitian ini adalah sebagai berikut (1) Kualitas pelayanan secara signifikan memberikan pengaruh yang positif terhadap kepuasan nasabah. (2) Demografi secara signifikan tidak memberikan pengaruh terhadap kepuasan nasabah. (3) Demografi sebagai variabel moderasi memperlemah hubungan antara kualitas pelayanan terhadap kepuasan nasabah namun pengaruhnya tidak signifikan.

Kata kunci: Kualitas pelayanan, Kepuasan Nasabah dan Demografis

\section{Pendahuluan}

Dunia perbankan di Indonesia pada saat ini telah terbagi menjadi dua jenis, yaitu bank yang bersifat konvensional dan bank yang bersifat syariah. Bank konvensional adalah bank yang dalam kegiatan operasionalnya menjalankan sistem bunga. Sedangkan bank syariah adalah bank yang dalam kegiatan operasionalnya tidak menggunakan sistem bunga, akan tetapi menggunakan sistem bagi hasil.

Pemberian pinjaman dengan mengenakan bunga pada Bank, adalah suatu hal yang lumrah namun tidak demikian pada Bank syariah. Pada pelaksanaan pemberian pembiayaan, Bank syariah melakukan kegiatannya berlandaskan syariah, di mana bank-bank syariah mengutamakan unsur kepercayaan dalam pemberian pembiayaan yang dilakukan. Dengan demikian sebelum bank syariah memberikan pembiayaan pada calon nasabah, Bank syariah

harus mempunyai informasi-informasi yang mendukung, melakukan pengawasan secara ketat, serta analisa pemberian kredit yang lebih selektif agar resiko adanya kredit macet dapat diminimalisasi. 
Pada penelitian ini, tingkat kepuasan nasabah terhadap pelayanan, yang akan diukur adalah pelayanan pada sektor pembiayaan. Salah satu bentuk pembiayaan yang dilakukan oleh bank syariah dalam pelaksanaan prinsip bagi hasil adalah pembiayaan murabahah.

Penurunan jumlah nasabah di Bank Syariah Mandiri Cabang Binjai, dapat terjadi akibat ketidakpuasan nasabah terhadap Bank. Ketidakpuasan tersebut bisa saja dikarenakan pelayanan pada produk pembiayaan dan proses pembiayaan dinilai kurang memenuhi harapan nasabah, sehingga nasabah yang merasa tidak puas bercerita atau memberitahu kepada orang lain.

Untuk itu maka, penelitian ini akan melihat seberapa besar pengaruh pelayanan Bank Syariah Mandiri Cabang Binjai yang terdiri atas tangibles, reliability, responsiveness, assurance, dan emphaty terhadap kepuasan nasabah dengan umur sebagai moderasi.

\section{Studi Literatur}

\section{Pembiayaan Menurut Syariah}

Menurut (Harahap : 2005) jenis pembiayaan menurut syariah terdiri atas:

a. Pembiayaan Salam

Salam adalah akad jual beli muslam fiih (barang pesanan) dengan penangguhan pengiriman oleh muslam iliahi (penjual) dan pelunasannya dilakukan segera oleh pembeli sebelum barang pesanan tersebut diterima sesuai dengan syarat-syarat tertentu.

b. Pembiayaan istishna

Ishtisna adalah akad jual beli antara al-mustashrii (pembeli) dan as shani (produsen yang juga bertindak sebagai penjual). Berdasarkan akad tersebut, pembeli menugasi produsen untuk menyediakan al-mashnu (barang pesanan) sesuai spesifikasi yang disyaratkan pembeli dan menjualnya dengan harga yang disepakati. Cara pembayaran dapat berupa pembayaran dimuka, cicilan, atau ditangguhkan sampai jangka waktu tertentu.

c. Pembiayaan Ijarah

Ijarah adalah akad sewa-menyewa antara pemilik ma'jur (obyek sewa) dan musta jir (penyewa) untuk mendapatkan imbalan atas obyek sewa yang disewakannya. Ijarah muntahiyah bittamlik adalah akad sewa menyewa antara pemilik obyek sewa dengan penyewa untuk mendapatkan imbalan atas obyek sewa yang disewakannya dengan opsi perpindahan hak milik obyek sewa pada saat tertentu sesuai dengan akad sewa.

d. Pembiayaan Musyarakah

Musyarakah adalah akad kerjasama di antara para pemilik modal yang mencampurkan modal mereka untuk mencari tujuan mencari keuntungan. Dalam musyarakah mitra dan bank sama-sama menyediakan modal untuk membiayai suatu usaha tertentu, baik yang sudah berjalan maupun yang baru. Selanjutnya mitra dapat mengembalikan modal tersebut berikut bagi hasil yang telah disepakati secara bertahap atau sekaligus kepada bank.

e. Pembiayaan Murabahah

Murabahah adalah pembiayaan dengan system jual beli, dimana bank syariah dapat membantu anggotanya denga membiayai pembelian barang yang dibutuhkan modal usaha anggota tersebut.

f. Pembiayaan Mudharabah

Mudharabah adalah pembiayaan dengan sistem bagi hasil, dimana bank syariah dapat membantu anggotanya dengan membagi keuntungan yang telah disepakati. 


\section{Pengertian Pelayanan}

Pelayanan merupakan suatu kegiatan yang diberikan produsen kepada konsumen atau perusahaaan/instansi kepada publik untuk memberi rasa puas dan menanggapi respon konsumen. Pelayanan memiliki banyak arti dan pandangan berbeda-beda dari setiap individu. Pelayanan yang mengesankan, yang istimewa, dapat menyebabkan kesetiaan pelanggan; misalnya, dalam bentuk pra-jual, kegiatan menjual, maupun purna-jual yang handal.

\section{Karakteristik Pelayanan}

Menurut (Kasmir : 2012) terdapat beberapa ciri-ciri pelayanan yang baik yang harus diikuti oleh karyawan yang bertugas melayani pelanggan/nasabah:”

a. $\quad$ Tersedianya karyawan yang baik

b. Tersedianya sarana dan prasarana yang baik

c. Bertanggung jawab kepada setiap nasabah sejak awal hingga selesai

d. Mampu melayani secara cepat dan tepat

e. Mampu berkomunikasi

f. Memberikan jaminan kerahasiaan setiap transaksi

g. Memiliki pengetahuan dan kemampuan yang baik

h. Berusaha memahami kebutuhan nasabah

i. Mampu memberikan kepercayaan kepada nasabah.

\section{Pengertian Kepuasan Nasabah}

Kepuasan pelanggan (customer satisfaction) tergantung pada kinerja anggapan produk relatif terhadap ekspektasi pembeli. Jika kinerja produk tidak memenuhi ekspektasi, pelanggan kecewa. Jika kinerja produk sesuai dengan ekspektasi, pelanggan puas. Jika kinerja melebihi ekspektasi, pelanggan sangat puas (Kotler dan Armstrong : 2008).

Menurut (Irawan:2009) factor yang mempengaruhi kepuasan pelanggan adalah:

a. Kualitas produk

b. Harga

c. Kualitas pelayanan

d. Faktor emosional

e. Kemudahan

\section{Demografi}

Sebagaimana dikemukakan oleh Kotler (1997) bahwa segmentasi konsumen dapat dikelompokkan berdasarkan demografi, psykhografis, geografis dan perilaku. Segmentasi demografi membagi konsumen berdasarkan usia, jenis kelamin, pekerjaan, pendidikan, status perkawinan, pendapatan, agama dan kebangsaan. Faktor demografi ini merupakan dasar yang paling populer dalam mengklasifikasi konsumen. Salah satu alasannya adalah bahwa kebutuhan dan keinginan konsumen biasanya berhubungan erat dengan variabel-variabel demografi.

\section{Metode Penelitian Teknik Pengumpulan Data}

Metode pengumpulan data yang digunakan dalam penelitian ini adalah dengan cara sebagai berikut:

1. Studi dokumentasi mengumpulkan dan mengolah data dan informasi yang diperoleh yang berhubungan dengan masalah yang diteliti. 
2. Studi kepustakaan (library research). Dalam hal ini, peneliti mempelajari buku-bukuyang memuat teori yang berhubungan dengan permasalahan yang diteliti, yaitu melalui tulisan ilmiah, masalah yang ada hubungannya dengan penelitian ini dan dapat membantu memecahkan masalah yang diteliti dan hasilnya akan dijadikan sebagai bahan perbandingan terhadap informasi yang di dapatkan di lapangan.

3. Pengamatan (observasi) yaitu suatu teknik pengumpulan data, dimana responden tidak mengetahui sedang dijadikan sumber data atau penelitian (respondent pasif). Pengamatan terhadap rutinitas dilokasi penelitian, lansung terhadap objek yang diteliti. Data yang dikumpulkan dalam penelitian ini disebut data sekunder.

4. Wawancara yaitu mengadakan kontak lansung dengan para staf dari kepala bagian yang ada hubungannya dengan masalah yamng sedang di teliti.

5. Kuesioner yaitu membuat pertanyaan / kuesioner yang akan dibagikan kepada responden yang menjadi objek penelitian dengan cara memilih salah satu jawaban yang telah dipersiapkan pada lembaran kuesioner, dan penilaian yang dilakukan dengan menggunakan skala likert. Skala likert yang digunakan yaitu:

a. Sangat Puas (SP) dengan skor 5

b. Puas $(\mathrm{P})$ dengan skor 4

c. Kurang Puas (KP) dengan skor 3

d. Tidak Puas (TP) dengan skor 2

e. Sangat Tidak Puas (STP) dengan skor 1

\section{Hasil}

\section{Uji Validitas dan Reliabilitas}

Setiap variabel pada butir kuesioner dalam penelitian ini, dilakukan uji validitas dan reliabilitas.

Hasil uji validitas kualitas pelayanan Item-Total Statistics

\begin{tabular}{|l|c|c|}
\hline & $\begin{array}{c}\text { Corrected Item-Total } \\
\text { Correlation }\end{array}$ & Keterangan \\
\hline Reliability & .610 & Valid \\
\hline Tangibility & .575 & Valid \\
\hline Responsiveness & .435 & Valid \\
\hline Assurance & .418 & Valid \\
\hline Emphaty & .343 & Valid \\
\hline
\end{tabular}

dapat dilihat bahwa pengujian instrumen variabel kualitas pelayanan menunjukkan bahwa semua nilai Corrected Item Total lebih besar dari 0,30. Hal ini menunjukkan bahwa instrumen penelitian dikatakan valid dan selanjutnya dapat digunakan dalam penelitian.

\section{Hasil uji validitas kepuasan nasabah Item-Total Statistics}

\begin{tabular}{|c|c|c|}
\hline & $\begin{array}{c}\text { Corrected Item-Total } \\
\text { Correlation }\end{array}$ & Keterangan \\
\hline
\end{tabular}




\begin{tabular}{|l|r|c|}
\hline Harapan nasabah & .622 & Valid \\
\hline Tujuan nasabah & .622 & Valid \\
\hline
\end{tabular}

dapat dilihat bahwa pengujian instrumen variabel kepuasan nasabah menunjukkan bahwa semua nilai Corrected Item Total lebih besar dari 0,30. Hal ini menunjukkan bahwa instrumen penelitian dikatakan valid dan selanjutnya dapat digunakan dalam penelitian.

\section{Hasil Reliabilitas Kualitas Pelayanan dan Kepuasan Nasabah}

\begin{tabular}{|l|c|r|r|l|}
\hline No & Variabel & Cronbach's & N & Keterangan \\
\hline & & Alpha & of Items & \\
\hline 1 & Kualitas pelayanan & 713 & 5 & Reliabel \\
\hline 2 & Kepuasan nasabah & .750 & 2 & Reliabel \\
\hline
\end{tabular}

dapat dilihat bahwa pengujian reliabilitas instrumen variabel penelitian menunjukkan nilai Cronbach"s Alpha lebih besar dari 0,6 yang berarti bahwa instrumen variabel penelitian adalah reliabel.

\section{Analisis Statistik Deskriptif Tentang Kualitas Pelayanan ( $\left.\mathbf{X}_{1}\right)$}

\section{(Reliability)}

Apakah Transaksi yang Anda Lakukan Berjalan Cepat, Lancar dan Tidak Ada Gangguan Jaringan

\begin{tabular}{|c|c|c|}
\hline jawaban & \multicolumn{2}{|c|}{ jumlah persentase } \\
\hline Kurang puas & 4 & 7,5 \\
\hline Puas & 31 & 58,5 \\
\hline Sangat puas & 18 & 34,0 \\
\hline Total & 53 & 100,0 \\
\hline
\end{tabular}

dapat dilihat bahwa nasabah yang menjawab kurang puas sebanyak 4 orang (7,5\%), yang menjawab puas 31 orang $(58,5 \%)$, dan menjawab sangat puas 18 orang (34\%). Hal tersebut menunjukkan bahwa sebagian besar nasabah $(58,5 \%)$ merasa puas dengan transaksi yang dilakukan di Bank Syariah Mandiri Cabang Binjai.

(Tangibility)

Apakah ruangan Bank Syariah Mandiri Cabang Binjai bersih dan nyaman

\begin{tabular}{|c|c|c|}
\hline jawaban & jumlah & persentase \\
\hline Kurang puas & 5 & 9,4 \\
\hline Puas & 27 & 50,9 \\
\hline Sangat puas & 21 & 39,6 \\
\hline Total & 53 & 100,0 \\
\hline
\end{tabular}

di atas dapat dilihat bahwa nasabah yang menjawab kurang puas sebanyak 5 orang $(9,4 \%)$, yang menjawab puas 27 orang $(50,1 \%)$, dan menjawab sangat puas 21 orang $(39,6 \%)$. Hal tersebut menunjukkan bahwa 
sebagian besar nasabah $(50,1 \%)$ merasa puas dengan ruangan yang tersedia oleh Bank Syariah Mandiri Cabang Binjai.

\section{(Responsiveness)}

Apakah Bapak/Ibu Puas dengan Pelayanan Mengenai Keluhan Bapak/Ibu pada Bank syariah Mandiri Cabang Binjai

\begin{tabular}{|c|c|c|}
\hline jawaban & jumlah & persentase \\
\hline Kurang puas & 3 & 5,7 \\
\hline Puas & 32 & 60,4 \\
\hline Sangat puas & 18 & 34,0 \\
\hline Total & 53 & 100,0 \\
\hline
\end{tabular}

di atas dapat dilihat bahwa nasabah yang menjawab kurang puas sebanyak 3 orang $(5,7 \%)$, yang menjawab puas 32 orang $(60,4 \%)$, dan menjawab sangat puas 18 orang $(34,0 \%)$. Hal tersebut menunjukkan bahwa sebagian besar nasabah $(60,4 \%)$ merasa puas dengan pelayanan atas keluhan yang dilakukan nasabah Bank Syariah Mandiri Cabang Binjai.

\section{(Assurance)}

Apakah Bapak/Ibu Merasa Aman dan Percaya Ketika Bapak/Ibu Bertransaksi di Bank Syariah Mandiri Cabang Binjai

\begin{tabular}{|c|c|c|}
\hline jawaban & Jumlah & persentase \\
\hline Kurang puas & 1 & 1,9 \\
\hline Puas & 31 & 58,5 \\
\hline Sangat puas & 21 & 39,6 \\
\hline Total & 53 & 100,0 \\
\hline
\end{tabular}

di atas dapat dilihat bahwa nasabah yang menjawab kurang puas sebanyak 1 orang $(1,9 \%)$, yang menjawab puas 31 orang $(58,5 \%)$, dan menjawab sangat puas 21 orang $(39,6 \%)$. Hal tersebut menunjukkan bahwa sebagian besar nasabah $(58,5 \%)$ merasa aman dan percaya pada saat bertransaksi di Bank Syariah Mandiri Cabang Binjai.

\section{(Emphaty)}

\section{Apakah Karyawan Bank Syariah Mandiri Cabang Binjai} Sabar dalam Melayani Bapak/Ibu

\begin{tabular}{|c|c|c|}
\hline \multicolumn{3}{|c|}{ Jumlah Persentase } \\
\hline Jawaban & 5 & 9,4 \\
\hline Kurang puas & 20 & 37,7 \\
\hline Puas & 28 & 50,9 \\
\hline Sangat puas & 53 & 100,0 \\
\hline Total & 5
\end{tabular}

dapat dilihat bahwa nasabah yang menjawab kurang puas sebanyak 5 orang $(9,4 \%)$, yang menjawab puas 20 orang $(37,7 \%)$, dan menjawab sangat puas 27 orang $(50,9 \%)$. Hal tersebut menunjukkan bahwa sebagian besar nasabah $(50,9 \%)$ merasa puas terhadap Bank Syariah Mandiri Cabang Binjai atas kesabaran karyawan dalam melayani keperluan nasabah. 


\section{Analisis Statistik Deskriptif Tentang Umur $\left(\mathbf{X}_{2}\right)$}

Umur

\begin{tabular}{|c|c|c|}
\hline Umur (Tahun) & Jumlah & Persentase (\%) \\
\hline$\leq \mathbf{3 0}$ & $\mathbf{0}$ & $\mathbf{0}$ \\
\hline $\mathbf{3 1 - 4 0}$ & $\mathbf{2 3}$ & $\mathbf{4 3 , 4 0}$ \\
\hline $\mathbf{4 1}-\mathbf{5 0}$ & $\mathbf{2 9}$ & $\mathbf{5 4 , 7 2}$ \\
\hline$>\mathbf{5 0}$ & 1 & $\mathbf{1 , 8 9}$ \\
\hline Total & $\mathbf{5 3}$ & \\
\hline
\end{tabular}

dapat dilihat bahwa nasabah yang paling banyak melakukan kredit adalah yang berumur 31 - 40 tahun $(43,40 \%)$, yang berumur 41 - 50 tahun $(54,72 \%)$, umur $>50$ tahun $(1,89 \%)$. Dengan begitu dapat disimpulkan bahwa nasabah yang mengajukan kredit terbanyak berusia diantara 41 - 50 tahun.

\section{Analisis Statistik Deskriptif Tentang Kepuasan Nasabah (Y)}

(Kepuasan Nasabah)
\begin{tabular}{|c|c|} 
Apakah Bapak/Ibu Merasa Bahwa Pencairan Dana Pinjaman \\
Sesuai dengan Nominal yang Bapak/Ibu Harapkan
\end{tabular}
\begin{tabular}{|c|c|c|}
\hline jawaban & Jumlah & persentase \\
\hline Tidak puas & 1 & 1,9 \\
\hline Kurang puas & 26 & 49,1 \\
\hline Puas & 17 & 32,1 \\
\hline Sangat puas & 9 & 17,0 \\
\hline Total & 53 & 100,0 \\
\hline
\end{tabular}

dapat dilihat bahwa nasabah yang menjawab tidak puas sebanyak 1 orang $(1,9 \%)$, yang menjawab kurang puas 26 orang $(49,1 \%)$, menjawab puas 17 orang $(32,1 \%)$, dan menjawab sangat puas 9 orang $(17,0 \%)$. Hal tersebut menunjukkan bahwa kebanyakan nasabah $(49,1 \%)$ merasa kurang puas dengan nilai kredit yang diberikan oleh Bank Syariah Mandiri Cabang Binjai.

(Kepuasan Nasabah)
$\begin{gathered}\text { Apakah Bapak/Ibu Merasa Puas dengan Kecepatan Proses } \\
\text { Percairan dana Pinjaman yang Dilakukan Pihak BSM } \\
\text { Cabang Binjai }\end{gathered}$
\begin{tabular}{|c|c|c|}
\hline Jawaban & Jumlah & persentase \\
\hline Tidak puas & 3 & 5,7 \\
\hline Kurang puas & 16 & 30,2 \\
\hline Puas & 27 & 50,9 \\
\hline Sangat puas & 7 & 13,2 \\
\hline Total & 53 & 100,0 \\
\hline
\end{tabular}

dapat dilihat bahwa nasabah yang menjawab tidak puas sebanyak 3 orang $(5,7 \%)$, yang menjawab kurang puas 16 orang (30,2\%), menjawab puas 27 orang (50,9\%), dan menjawab sangat puas 7 orang $(13,2 \%)$. Hal tersebut menunjukkan bahwa sebagian besar nasabah $(50,9 \%)$ merasa puas dengan kecepatan proses pencairan dana yang dilakukan oleh Bank Syariah Mandiri Cabang Binjai. Nasabah yang merasa puas dengan nilai kredit yang diberikan oleh Bank Syariah Mandiri cabang Binjai sekitar 51\%. 


\section{Moderating Regression Analysis (MRA)}

Analisis ini menggunakan 3 variabel yaitu, variabel bebas yaitu kualitas pelyanan $\left(\mathrm{X}_{1}\right)$ dan demografi $\left(\mathrm{X}_{2}\right)$, dan variabel terikat yaitu kepuasan nasabah $(\mathrm{Y})$. Dengan demikian model analisis moderator yang terdapat dalam kerangka konsep dapat ditulis persamaan strukturnya sebagai berikut:

$$
\begin{gathered}
Y=a+b_{1} X_{1}+b_{2} X_{2}+b_{3} X_{1} X_{2}+- \\
Y=0,040+0,823 X_{1}+0,142 X_{2}-0,032 X_{1} X_{2}
\end{gathered}
$$

\subsection{Uji Determinasi}

Untuk melihat kemampuan variabel bebas dalam menjelaskan variabel terikat.

\begin{tabular}{|l|l|r|c|c|}
\multicolumn{7}{|c}{ Model Summary $^{\mathbf{b}}$} \\
\hline Model & $\mathrm{R}$ & R Square & $\begin{array}{c}\text { Adjusted R } \\
\text { Square }\end{array}$ & $\begin{array}{c}\text { Std. Error of the } \\
\text { Estimate }\end{array}$ \\
\hline 1 & $.806^{\mathrm{a}}$ & .650 & .628 & .60974737 \\
\hline
\end{tabular}

a. Predictors: (Constant), x3, Zscore: pelayanan, Zscore: demografi(usia)

b. Dependent Variable: Zscore: kepuasan nasabah

dapat dilihat bahwa variabel kualitas pelayanan $\left(\mathrm{X}_{1}\right)$, dan demografi $\left(\mathrm{X}_{2}\right)$ mampu menjelaskan kepuasan nasabah (Y) sebesar 65\%, sedangkan sisanya sebesar 35,0\%

kepuasan nasabah dipengaruhi oleh faktor-faktor lain di luar penelitian ini. Hal tersebut menunjukkan bahwa kualitas pelayanan yang terdiri atas indikator assurance, tangible, responsiveness, reliability dan emphaty dan variabel demografi yang terdiri atas umur mampu menjelaskan kepuasan nasabah Bank Syariah Mandiri Cabang Binjai sekitar 65\%.

\section{Uji asumsi klasik}

Pada pengujian asumsi klasik menggunakan tiga uji yaitu uji normalitas, uji multikolinearitas, dan uji heterokedastisitas.

\section{Uji Normalitas}

\section{One-Sample Kolmogorov-Smirnov Test}

\begin{tabular}{|l|l|r|}
\hline \multicolumn{2}{|l|}{} & $\begin{array}{r}\text { Standardized } \\
\text { Residual }\end{array}$ \\
\hline$N$ & & 53 \\
\hline Normal Parameters ${ }^{\mathrm{a}, \mathrm{b}}$ & Mean & .0000000 \\
\hline & Std. Deviation & .97072534 \\
\hline $\begin{array}{l}\text { Most Extreme } \\
\text { Differences }\end{array}$ & Absolute & .107 \\
\hline & Positive & .107 \\
\hline & & -.094 \\
Negative & .778 \\
\hline Kolmogorov-Smirnov Z & .580 \\
\hline Asymp. Sig. (2-tailed) &
\end{tabular}




\begin{tabular}{|l|l|}
\hline & \\
\hline a. Test distribution is Normal. & \\
\hline b. Calculated from data. & \\
\hline
\end{tabular}

dapat dilihat hasil pengujian One-Sample Kolmogorov-Smirnov Test, dimana diperoleh hasil bahwa data berdistribusi normal karena nilai asymp.sig lebih besar dari 0.05 yaitu sebesar

0.580 .

\section{Uji Multikolinearitas}

\begin{tabular}{|l|l|l|l|}
\hline \multicolumn{2}{|c|}{ Coefficients $^{\mathbf{a}}$} & \multicolumn{2}{l|}{ Collinearity Statistics } \\
\cline { 3 - 4 } \multicolumn{2}{|l}{ Model } & Tolerance & VIF \\
\cline { 3 - 4 } & & & \\
\hline 1 & (Constant) & & \\
\hline & Zscore: pelayanan & .958 & 1.044 \\
\hline & Zscore: demografi(usia) & .912 & 1.097 \\
\hline & x3(moderating) & .946 & 1.057 \\
\hline & & & \\
\hline
\end{tabular}

a. Dependent Variable: Zscore: kepuasan nasabah

dapat dilihat bahwa hasil perhitungan nilai Variance Inflation Factor (VIF) menunjukkan tidak ada variabel bebas yang memiliki nilai VIF lebih besar dari 10. Jadi dapat disimpulkan bahwa tidak terjadi multikolineritas antar variabel bebas dalam model penelitian ini.

\section{Uji Heterokedastisitas}

terlihat bahwa titik-titik menyebar di atas dan di bawah angka 0 pada sumbu Y. Oleh karena itu dapat dinyatakan bahwa persamaan regresi terbebas dari asumsi heteroskedastisitas, sehingga hasil penelitian ini dapat diterima dan dilanjutkan pengujian hipotesis.

\section{Scatterplot}

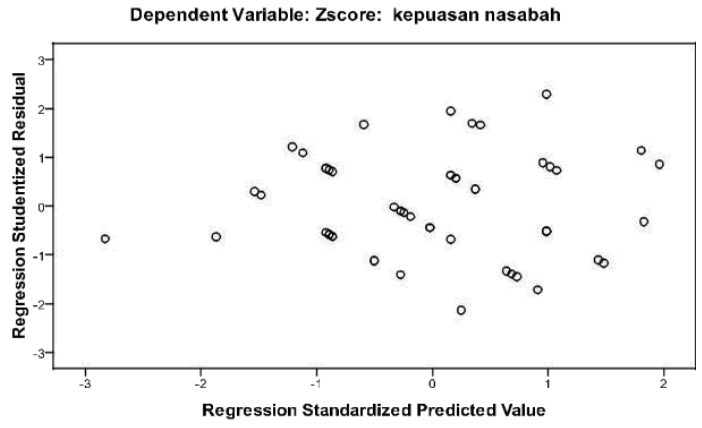

Terlihat bahwa titik-titik menyebar di atas dan di bawah angka 0 pada sumbu Y. Oleh karena itu dapat dinyatakan bahwa persamaan regresi terbebas dari asumsi heteroskedastisitas, sehingga hasil penelitian ini dapat diterima dan dilanjutkan pengujian hipotesis.

\section{UJI HIPOTESIS}


Uji hipotesis dalam penelitian ini dilakukan dengan menggunakan uji f dan uji t.

\section{Uji f (Serempak)}

Untuk melakukan pengujian hipotesis dapat dilakukan dengan melihat Tabel Anova pada nilai probabilitas/nilai sig pada tabel keluaran Anova. Untuk melakukan pengujian hipotesis dengan uji F maka hipotesis dapat dibuat sebagai berikut:

Ho : : Tidak ada pengaruh yang positif dan signifikan antara kualitas pelayanan, dan demografi sebagai variabel moderasi terhadap kepuasan nasabah.

H1 : Terdapat pengaruh yang positif dan signifikan antara kualitas pelayanan, dan demografi sebagai variabel moderasi terhadap kepuasan nasabah.

Untuk melihat hasil pengujian hipotesis di atas maka dapat dilihat pada Tabel di bawah ini:

\begin{tabular}{|c|c|c|c|c|c|c|}
\hline \multicolumn{6}{|c|}{ ANOVA $^{\text {b }}$} & \multirow[b]{2}{*}{ Sig. } \\
\hline Model & & Sum of Squares df & & Mean Square & & \\
\hline 1 & Regression & 33.782 & 3 & 11.261 & 30.288 & $.000^{2}$ \\
\hline & Residual & 18.218 & 49 & .372 & & \\
\hline & Total & 52.000 & 52 & & & \\
\hline
\end{tabular}

a. Predictors: (Constant), x3, Zscore: pelayanan, Zscore: demografi(usia)

b. Dependent Variable: Zscore: kepuasan nasabah dapat dilihat bahwa nilai $F_{\text {hitung }}$ sebesar 30,28 dan nilai signifikansi 0,00. Oleh karena itu $\mathrm{H}_{0}$ ditolak dan $\mathrm{H}_{1}$ diterima, yang berarti bahwa variabel pelayanan, dan demografi sebagai moderating berpengaruh secara bersama-sama terhadap variabel kepuasan nasabah. Kualitas pelayanan dan demografi secara serempak berpengaruh terhadap kepuasan nasabah. Berpengaruh signifikannya kualitas pelayanan dan demografi terhadap kepuasan nasabah, menunjukkan bahwa kualitas pelayanan dan demografi menjadi faktor yang penting dalam menentukan kepuasan nasabah.

Uji t (Uji Parsial)

Tabel 4.19

Coefficients $^{\mathrm{a}}$

\begin{tabular}{|c|c|c|c|c|c|c|c|c|c|}
\hline \multirow{3}{*}{ Model } & \multirow{2}{*}{\multicolumn{2}{|c|}{$\begin{array}{l}\text { Unstandardized } \\
\text { Coefficients }\end{array}$}} & \multicolumn{3}{|c|}{ Standardized } & \multicolumn{2}{|c|}{$\begin{array}{r}95.0 \% \text { Confidence } \\
\text { Interval for B }\end{array}$} & \multicolumn{2}{|c|}{$\begin{array}{c}\text { Collinearity } \\
\text { Statistics }\end{array}$} \\
\hline & & & Coeff & ficients & & \multirow{2}{*}{$\begin{array}{l}\text { Lower } \\
\text { Bound }\end{array}$} & \multirow{2}{*}{$\begin{array}{l}\text { Upper } \\
\text { Bound }\end{array}$} & \multirow[b]{2}{*}{ Tolerance } & \multirow[b]{2}{*}{ VIF } \\
\hline & $\mathrm{B}$ & Std. Error & Beta & $\mathrm{t}$ & Sig. & & & & \\
\hline & & & & & & & & & \\
\hline 1 (Constant) & .040 & .151 & & 267 & .790 & -.262 & .343 & & \\
\hline Zscore: pelayanan & .823 & .086 & .823 & 9.529 & .000 & .650 & .997 & .958 & 1.044 \\
\hline Zscore: demografi(usia) & .142 & .089 & .142 & 1.600 & .116 & -.036 & .320 & .912 & 1.097 \\
\hline x3(moderating) & -.032 & .099 & -.028 & -.322 & 749 & -.230 & .167 & .946 & 1.057 \\
\hline & & & & & & & & & \\
\hline
\end{tabular}

a. Dependent Variable: Zscore: kepuasan nasabah

\section{Pembahasan}

Hubungan antara variable kualitas pelayanan dengan variabel dependen kepuasan nasabah

Pada variabel independen kualitas pelayanan dengan variabel dependen kepuasan nasabah, uji t hipotesis seperti di bawah ini: 
$\mathrm{H}_{0}=$ Tidak ada hubungan yang positif signifikan antara variabel Pelayanan dengan variabel kepuasan nasabah

$\mathrm{H}_{1}=$ Ada hubungan yang positif signifikan antara variabel Pelayanan dengan variabel kepuasan nasabah

\section{Hasil dari uji $\mathbf{t}$ pada hipotesis di atas adalah terima $\mathrm{H}_{1}$ dan tolak $\mathrm{H}_{0}$}

Hasil pengujian menunjukkan bahwa variabel pelayanan terhadap kepuasan nasabah diperoleh nilai koefisien yang positif sebesar 0,823 dan signifikan ( $\operatorname{sig}=0,000$ ). Hasil ini menunjukkan bahwa semakin baik pelayanan yang diberikan kepada nasabah akan berdampak pada peningkatan kepuasan nasabah.

Nilai koefisien sebesar 0,823 juga dapat diartikan bahwa, jika kualitas pelayanan dinaikkan $1 \%$ maka kepuasan nasabah juga akan meningkat sebesar 0,823\%. Maka berdasarkan hal tersebut dapat dinyatakan bahwa, hubungan antara kualitas pelayanan dengan kepuasan nasabah adalah positf, yaitu apabila kualitas pelayanan ditingkatkan maka kepuasan nasabah juga ikut meningkat.

\section{Hubungan antara variabel demografi dengan variabel dependen kepuasan nasabah}

Pada variabel independen kualitas pelayanan dengan variabel dependen kepuasan nasabah, uji t hipotesis seperti di bawah ini:

$\mathrm{H}_{0}=$ Tidak ada hubungan antara variabel demografi dengan variabel kepuasan nasabah $\mathrm{H}_{1}=\mathrm{Ada}$ hubungan antara variabel demografi dengan variabel kepuasan nasabah

\section{Hasil dari uji t pada hipotesis di atas adalah tolak $\mathrm{H}_{1}$ dan terima $\mathrm{H}_{0}$}

Hasil pengujian menunjukkan bahwa variabel demografi (usia) terhadap kepuasan pelanggan diperoleh nilai koefisien positif sebesar 0,142 dan tidak signifikan (sig=0,116). Hal ini menunjukkan bahwa usia secara signifikan tidak memberikan pengaruh terhadap kepuasan nasabah.

Hasil tersebut dapat diartikan bahwa usia nasabah tidak memberikan dampak terhadap kepuasan nasabah hanya atau dengan kata lain, tidak ada pengaruh antara usia dengan kepuasan nasabah pada BSM cabang Binjai.

\section{C.3 Moderating}

$\mathrm{H}_{0}=$ Demografi tidak memoderasi hubungan antara pelayanan terhadap kepuasan nasabah.

$\mathrm{H}_{1}=$ Demografi memoderasi hubungan antara pelayanan terhadap kepuasan nasabah.

Hasil pengujian menunjukkan bahwa variabel demografi (usia) dalam memoderasi hubungan antara pelayanan terhadap kepuasan nasabah diperoleh nilai koefisien yang negatif sebesar $-0,032$ dan tidak signifikan (sig=0.749). Hasil ini menunjukkan bahwa demografi usia memberi pengaruh negatif terhadap hubungan antara variabel pelayanan terhadap kepuasan nasabah, dengan kata lain usia nasabah tidak berpengaruh terhadap kepuasan nasabah.

Berdasarkan Tabel 4.17 di atas menunjukkan bahwa demografi (usia) dengan angka yang negatif diartikan bahwa, usia memperlemah hubungan antara pelayanan terhadap kepuasan nasabah. Namun meskipun usia memperlemah hubungan antara pelayanan dengan kepuasan nasabah, kemampuan demografi memperlemah tersebut tidak berpengaruh secara signifikan atau dengan kata lain dapat diabaikan. 


\section{Demografi Memoderasi Pengaruh Kualitas Pelayanan Terhadap Kepuasan Nasabah}

Berdasarkan hasil pengujian menunjukkan bahwa variabel demografi tidak secara nyata mampu memoderasi pengaruh antara kualitas pelayanan terhadap kepuasan nasabah. Hal ini menunjukkan variabel demografi tidak mampu secara nyata memperkuat ataupun memperlemah hubungan antara kualitas pelayanan terhadap kepuasan nasabah. Variabel demografi yang diwakili usia tidak mampu secara nyata memberi dampak akan pengaruh dari kepuasan nasabah yang ditentukan oleh perubahan kualitas pelayanan yang berlaku pada bank syariah Mandiri Cabang Binjai.

\section{Pembahasan Secara Serempak}

Transaksi yang dilakukan di BSM cabang Binjai sudah berjalan dengan lancar, dan gangguan jaringan pun tidak terlalu menjadi hal yang perlu dirisaukan olah nasabah. Ruangan dan pelayanan yang diberikan di BSM cabang Binjai dinilai sudah baik oleh nasabah, begitu juga dengan rasa aman dan kepercayaan yang diberikan oleh pihak BSM cabang Binjai. Namun dalam pencairan dana kredit pihak nasabah banyak yang merasa kurang puas, hal tersebut dikarenakan nilai kredit yang disetujui pihak BSM cabang Binjai masih jauh dari apa yang diharapkan oleh nasabah.

Demografi yang dalam penelitian ini adalah usia memperlemah hubungan antara kualitas pelayanan dengan kepuasan nasabah. Usia merupakan variabel moderasi, namun kemampuan usia dalam memperlemah hubungan antara kualitas pelayanan dengan kepuasan nasabah tidak siginifikan. Hal tersebut menunjukkan kemampuan usia dalam memperlemah hubungan kedua variabel ini dapat diabaikan, atau dengan kata lain kemampuan usia tidak kuat dalam memperlemah kualitas pelayanan dengan kepuasan nasabah.

\section{Kesimpulan}

Berdasarkan hasil dan pembahasan maka dapat dapat disimpulkan bahwa, kualitas pelayanan secara signifikan memberikan pengaruh yang positif terhadap kepuasan nasabah. Sedangkan demografi yang dalam penelitian ini berupa usia secara signifikan tidak memberikan pengaruh terhadap kepuasan nasabah. Demografi sebagai variabel moderasi memperlemah hubungan antara kualitas pelayanan terhadap kepuasan nasabah namun tidak signifikan pengaruhnya

\section{Referensi}

Algaoud, Latifa dan Mervyn, Lewis. (2010). Perbankan Syari'ah : Prinsip, Praktik Prospek. Terjemahan Burhan Wirasubrata. Jakarta : Penerbit Serambi.

Alma, Buchari, (2004), Manajemen Pemasaran dan Pemasaran Jasa, Alfabeta, Bandung.

Alsayyed, Nidal. 2010. The Uses and Misuses of Comodity Murabahah: Islamic Economic Perspective. Munich Personal RePEc Archive Journal. The Global University in Islamic Finance, Kuala Lumpur

Arifin, Zainul., (2012) Pembiayaan Syariah, Materi Pelatihan Syariah, Penerbit Maju, Medan.

Ayinde Lukman, Olorogun. 2012. Critical Evaluation of The Compatibility Between Traditional and Contemporary Applications of Murabahah Transactions. Aceh International Journal. 1: 31-37

Bayu Hadyanto Mulyono. 2008. Analisis Pengaruh Kualitas Produk dan Kualitas Layanan Terhadap Kepuasan Konsumen (Studi Kasus Pada Perumahan Puri Mediterania Semarang) [Tesis]. Semarang. Universitas Diponegoro Program Pasca Sarjana

Downe. G., Alan., Salim Mat, Hanisah.,Taiwo Adegbite, Ayankunle., Loke Phaik, Siew. 2011. Service Quality and Customer satisfactio in a Telecomunication Service Provider. LPEDR. 11: 24-29

Fandi, Tjiptono., (2008) Strategi Pemasaran.Yogyakarta:Andi Yogyakarta.

Fitzsimmons., (2009), Pelayanan Barang dan Jasa, Terjemahan Alih Bahasa Ellen Gunawan Sitompul, Uka Wikarya, dan Anton Hendranata, Kanisius, Yogyakarta.

Harahap, Sofyan S, Wiroso, Yusuf, Muhammad, (2005). Akuntansi Perbankan Syariah. 
LPFE Usakti : Jakarta.

IAI, (2007). Standar Akuntan Keuangan, PSAK No. 105. Salemba Empat : Jakarta. Irawan, Handi., (2009) Prinsip Kepuasan Pelanggan. Jakarta:PT. Elex Media Komputindo. Ismail.2010.Akuntansi Bank Surabaya:Kencana Prenada Media Group.

Iwan Triyuwono, (2006) Perspektif, Metodologi dan Teori Akuntansi Syariah, Penerbit PT. Raja Grafindo Persada, Jakarta

Juliandi, Azwar., (2013), Metode Penelitian Kuantitatif Untuk Ilmu-Ilmu Bisnis. Medan: M.2000.

Karim, Adiwarman, (2009). Bank Islam. Edisi Dua, PT. Raja Grafindo Persada : Jakarta.

Kasmir, (2012). Dasar-Dasar Perbankan. PT. Raja Grafindo Pers : Jakarta.

Kotler, Philip., (2008). Manajemen Pemasaran.Jakarta:Salemba Empat.

Kristianto, Paulus Lilik., (2011) Psikologi Pemasaran.Yogyakarta:CAPS.

Lupiyoadi Rambat, (2009), Menajemen Jasa, Teori dan Praktik, Edisi pertama, Salemba Empat, Jakarta.

Majid, Suharto Abdul., (2009) Customer Service dalam Bisnis Jasa. Jakarta:PT. Raja Grafindo Persada 